УДК 7.036

\title{
ВЗАИМОСВЯЗЬ ХУДОЖЕСТВЕННОГО ЯЗЫКА В ЖЕНСКИХ ОБРАЗАХ Л.Я. ТИМОШЕНКО И Е.А. КИБРИКА
}

\author{
Чичварина О. Г. \\ искусствовед, член Союза художников России \\ (секция искусствоведение) \\ арт-директор ООО «Издательско-торговая \\ компания "СВЕТАЛИНА"» \\ г. Москва
}

Аннотация: В данном исследовании освещается проблематика взаимовлияния художественного языка двух самобытных художников XX века Л.Я. Тимошенко и Е.А. Кибрика. Особая эстетика женских образов, созданных мастерами в станковой живописи и книжной графике представляет концептуальный диалог.

Образ Л.Я Тимошенко стал важной составляющей графического прочтения Е.А. Кибриком литературных персонажей Неле (в романе Ш. де Костера «Легенда об Уленшпигеле») и Аннеты Ривьер (в романе Р. Роллана «Очарованная душа»). Воздействие творчества Л.Я. Тимошенко на графическую манеру Е.А. Кибрика, для которого образность, идейность, интуиция и анализ, цельность формы были основными составляющими творческого метода, вызывает научный интерес.

Ключевые слова: графическое прочтение, портрет, живопись, иллюстрация, женский образ, литография, характеристика персонажа.

THE RELATIONSHIP BETWEEN ARTISTIC LANGUAGE IN L.Ya. TIMOSHENKO'S AND E. A. KIBRIK'S WOMEN'S IMAGES

Chichvarina O.G. Art historian, Member of the Russian Union of Artists (art criticism section) art director ltd. «Publishing and Trading Company "SVETALINA"» Moscow, Russian Federation

Abstract: This study highlights the problems of mutual influence of artistic language of two distinctive artists of the 20th century, L. Ya. Timoshenko and 
E.A. Kibrik. The special aesthetics of female images created by the masters in easel painting and book graphic art represents a conceptual dialogue.

The image of L. Ya. Timoshenko became an important component of E.A. Kibrrik's graphic reading of the literary characters of Nele (in the novel «The Legend of Ulenspiegel» by Charles de Koster) and Annette Riviere (in «The Enchanted Soul» by R. Rolland). The impact of Timoshenko's work on the graphic style of E. A. Kibrik, for whom imagery, ideology, intuition and analysis, integrity of form were the main components of the creative method, is of scientific interest.

Key words: graphic reading, portrait, painting, illustration, female character, lithography, character reference.

Лидия Яковлевна Тимошенко - живописец, график, книжный иллюстратор XX века, член ленинградского общества «Круг художников» (с 1928 года), существовавшего в 1926-1932 годах, член «Союза советских художников» (с 1932 года), исследователь иконы «Троица» Андрея Рублева.

В искусстве конца 1930-х годов Л.Я. Тимошенко «говорила» через утончённые, лирические портреты («Л. Радлова», «Девушка под зонтиком», «Портрет Стеллы Манизер», «Портрет М. Асламазян»), этюды с купанием подростков («На Дону», «На берегу»), живописные произведения, наполненные особой эстетикой преимущественно женских образов («Девочка с яблоком»), мерцающих солнечным светом, озаряющих облик юных героинь её полотен («Шепчутся», «Под яблоней», «Девочки на изгороди», «Казачки», «Катюша»), особой жизненностью и внутренним ритмом грациозных движений внутри картины, композицией открытого пространства световоздушной среды, будто размывающей очертания фигур и создающей тем самым иллюзию движения.

Всё это, безусловно, стало движущей силой влияния творчества Л.Я. Тимошенко на серии иллюстраций известного книжного графика XX века Е.А. Кибрика к «Легенде об Уленшпигеле» и в большей степени к «Очарованной душе». В будущем, спустя несколько десятилетий, нечто схожее с этой чистотой, лёгкостью и вместе с тем глубиной раскрытия характера мы увидим и в его иллюстрациях к «Портрету» Н. В. Гоголя. Самобытный талант Л. Я. Тимошенко отражает её внутренний мир, безгранично расширяющийся и выходящий за свои пределы, являя в её облике вдохновляющее начало, побуждающее создавать прекрасные женские образы в искусстве.

Впервые в творчестве Е.А. Кибрика глубокие чувства художника к Л.Я. Тимошенко проявились в изображении лирических сюжетов, воспетых 
Ш. Де Костером в «Легенде об Уленшпигеле» - в графическом прочтении возлюбленной Тиля - Неле. Женский образ возлюбленной графика стал прототипом образа художественного, воплощающего сердце Фландрии. Именно такой казалась она Е. А. Кибрику - любящей, доброй, нежной, верно и с трепетом ожидающей своего странника. Её мужество, как и мужество Неле было «нужно, чтобы сделать себя свободной. Пожалуй, человеку, - писала Л. Я. Тимошенко, - это труднее всего» [2, С. 51].

Творческий метод работы Е.А. Кибрика с Л.Я. Тимошенко, с использованием ключевых аспектов системы К.С. Станиславского, моментальные зарисовки с натуры, глубокое проникновение в исторический материал - всё в синтезе, во взаимодействии друг с другом рождало точный образ в мимике и жестах, в одежде, в графической характеристике персонажа. Наблюдения Е.А. Кибрика не только фиксировались им на бумаге, но и становились определенным синтезом фаз движений портретируемой, сохраняющим черты предшествовавшего и последующего положения в пространстве.

После триумфального успеха графического образа Ласочки в «Кола Брюньоне» Е.А. Кибрик стремился создать облик Неле (символизирующий в легендах Фландрии любовь) столь же выразительным, любимым зрителями и запоминающимся. В работе над серией художник постигает сложнейшие переплетения личностной психологии.

В литографии, повествующей о женской преданности в ожидании Тиля есть что-то доблестное, то необходимое звено в жизни, та часть и составляющая, которая необходима всем вне регалий и вне возрастов. На первый план выступает эмоциональное содержание, особая духовная наполненность, отражающая глубину внутренних переживаний Неле. Неустанный поиск и отбор продуманных внешне лаконичных форм приводит графика к строгой и выверенной композиции.

1939 год становится знаменательным в жизни графика не только потому, что в это время он приступает к изучению материалов, связанных с работой над «Очарованной душой», но и потому, что становится отцом, безгранично радуясь появлению на свет сына Александра, спустя год после скромно отмеченной свадьбы с Л.Я. Тимошенко. Единственным свидетелем свадебного торжества была художник М. Асламазян, из воспоминаний которой понятно, как благополучно до начала войны текла жизнь влюблённых друг в друга и в искусство Л.Я. Тимошенко и Е.А. Кибрика: «Для них это была изумительная пора. Они жили душа в душу, весёлые и счастливые» [3, С. 57]. 
В процессе графических поисков Е.А. Кибрик всегда делал множество эскизов. «Когда я должен создать образ своего героя, - вспоминал график, - то должен не только угадать его внешность, но и наполнить его признаками душевного мира - все вместе это будет тем, что в искусстве называется характером» [1, С. 121].

Рождение образа становилось для Е.А. Кибрика сродни ожиданию рождения младенца, процессом длительным, иногда затягивавшимся на многие месяцы. Л.Я. Тимошенко писала: «Всё «живое» таинственно и заманчиво. И рождение ребенка, и луна с солнцем, то есть законы природы, и жизнь людей, с их страстями, революциями, идеями, дерзаньем» [2, 50-51]. Её мысли и миропонимание как нельзя лучше подходили к образу Аннеты Ривьер.

Образ матери и младенца, созданный Е.А. Кибриком к роману Р. Роллана «Очарованная душа», в диалоге между героями иллюстрации становится единением душ и сердец в потоке света и любви. Лица Аннеты и Марка обращены друг к другу. Зритель невольно оказывается на месте младенца. Именно благодаря этой сопричастности образ побуждает к раскрытию в зрителе воспоминаний, вызывающих особый трепет. Рассказывая о безграничной материнской любви, Е.А. Кибрик уже в подготовительных эскизах выбирает момент, повествующий о слиянии двух родных существ и единении душ. Проникновенные отношения стали для художника особенно понятными и близкими в период рождения сына художника, совпавший с работой над «Очарованной душой».

Л.Я. Тимошенко с младенцем на руках в графическом прочтении Е.А. Кибрика становилась символом Вселенской матери Аннеты Ривьер. В процессе работы появилось множество вариантов рисунков, акварелей и цветных литографий «Мать и дитя» в разных колористических оттенках.

В художественном решении образов, от эскизов до оригинала, Е.А. Кибрик шёл по пути психологического раскрытия характера героя, ставя перед собой задачи проникновения в мировоззрение и внутренний мир человека. И «в лучшей из всех серий книжных иллюстраций, созданных Кибриком, - серии чёрных литографий к „Очарованной душе“ Р. Роллана, - явно и открыто чувствуется глубокое и плодотворное влияние искусства Лидии Яковлевны, пишет искусствовед А.Д. Чегодаев. - В ясной простоте и естественности композиций, в их пропитанности светом и воздухом, в тонкости психологических характеристик героев этих иллюстраций есть наглядно 
выступающее сродство с самыми важными качествами работ Лидии Яковлевны» [3, С. 9-10].

Графическое прочтение Е.А. Кибриком женского образа Л.Я. Тимошенко в книжных иллюстрациях не изобилует яркой, праздничной декоративностью. Его особенностью является психологическая завершенность, воплощение индивидуальности, естественность в передаче неповторимых черт и жизненной полнокровности литературных героинь, чьим воплощением в творческой судьбе графика явилась удивительной красоты женщина, жена, мать.

И Е.А. Кибрик и Л.Я. Тимошенко в своём творчестве стремились к раскрытию гармоничного женского образа, ценных духовных качеств: благородства, искренности, простоты, честности.

В послевоенный период меняется характер героинь Л.Я. Тимошенко с лирически-утонченного, довоенного, до внутренне-настороженного, отважного, стойкого и решительного («В саду», 1943; «С книгой», 1944; «Кавалеристдевица Надежда Дурова», 1945; «Зоя», 1948) в период тяжелых испытаний. Здесь ощутимо стилистическое влияние Е.А. Кибрика, монументальности его образов. Честность перед другими и перед собой - главная черта художественных произведений Л.Я. Тимошенко и Е.А. Кибрика. И отношение к портрету особенное. Каждый раз это акцент на личности героини, изображении характера, в котором прочитываются и угадываются её чувства, мысли. Проблематика художественного языка Е.А. Кибрика и Л.Я. Тимошенко в воплощении женских образов раскрывается и в самой личности художников, в их естестве и представлении мира героинь нам - своему зрителю.

\section{Список литературы}

1. Кибрик Е.А. Работа и мысли художника. [предисл. Верейского О.Г.]. М.: Искусство, 1984. - 255 с.

2. Лидия Тимошенко - художник и личность: Живопись. Графика. Дневники. Воспоминания современников / Сост. Кибрик А.Е. - М.: Советский художник, 1991. - 151 с.

3. Лидия Тимошенко. Реальность других измерений. Дневники. Письма. Воспоминания / Сост. Кибрик А.Е. [предисл. Чегодаева А.Д.]. М.: Прогресс-Традиция, 2004. - 271 с.

(C) О. Г. Чичварина, 2021 